\title{
Can Allelopathic Grasses limit Seed Germination and Seedling Growth of MUtambo? A Test with Two Species of Brachiaria GRASSES $^{1}$
}

\author{
Gramíneas Alelopáticas Podem Limitar a Germinação de Sementes e o Crescimento de \\ Plântulas de Mutambo? Um Teste com Duas Espécies de Braquiárias
}

OLIVEIRA, A.P.P. ${ }^{2}$, PEREIRA, S.R. ${ }^{3}$, CÂNDIDO, A.C.S. ${ }^{4}$, LAURA, V.A. ${ }^{2,4,5}$, and PERES, M.T.L.P. ${ }^{2}$

\begin{abstract}
Tree establishment in pasture areas can be inhibited, at least in part, by exotic grasses allelopathy and this can represent an important limitation by changing the patterns of both germination and seedling growth of tree species. This study aims to evaluate the allelopathic potential of Urochloa brizantha and U. decumbens on germination, growth and metabolism of Guazuma ulmifolia seedlings. We performed bioassays evaluating the effect of the crude ethanol extract and semipurified fractions (hexane fraction, ethyl acetate fraction and ethanol-water fraction) of $U$. brizantha and $U$. decumbens using completely randomized design, with four concentrations $\left(0,250,500,1,000 \mathrm{mg} \mathrm{L}^{-1}\right)$ and four replications. The variables analyzed were germination percentage, mean germination time, shoot and root growth, catalase and peroxidase activity, chlorophyll content and root respiration. The results showed that both grasses have an inhibitory effect on G. ulmifolia metabolism, affecting both germination and seedlings growth and inducting metabolic defense. Thus, these results show that the grass species evaluated have the potential to restrict the re-introduction of G. ulmifolia in pasture areas due to interference competition.
\end{abstract}

Keywords: Guazuma ulmifolia, interference competition, exotic grasses, direct sowing, restoration, Urochloa.

\begin{abstract}
RESUMO - O estabelecimento de espécies arbóreas em áreas de pastagens pode ser inibido, pelo menos em parte, pela alelopatia das gramineas, o que pode representar uma importante limitação por alterar tanto os padrões de germinação como os de crescimento de plântulas das espécies arbóreas. O objetivo deste estudo foi avaliar o potencial alelopático de Urochloa brizantha e U. decumbens na germinação, crescimento e metabolismo de plântulas de Guazuma ulmifolia. Foram realizados bioensaios em que se avaliou o efeito do extrato bruto e das frações semipurificadas (fração hexânica, fração acetato de etila e fração etanol/água) de U. brizantha e U. decumbens, usando delineamento completamente aleatorizado, com quatro concentrações $\left(0,250,500,1.000 \mathrm{mg} \mathrm{L}^{-1}\right)$ e quatro repetições. As variáveis analisadas foram porcentagem de germinação, tempo médio de germinação, crescimento da raiz primária da radícula e do hipocótilo, atividade da catalase e peroxidase, conteúdo de clorofila e respiração radicular. Os resultados mostraram que as duas gramineas apresentaram efeito inibitório no metabolismo de G. ulmifolia, afetando tanto a germinação como o crescimento de plântulas $e$ induzindo o metabolismo de defesa. Assim, esses resultados mostraram que as espécies de gramineas avaliadas têm o potencial de restringir a reintrodução de G. ulmifolia em áreas de pastagem devido à competição por interferência.
\end{abstract}

Palavras-chave: Guazuma ulmifolia, competição por interferência, gramíneas exóticas, semeadura direta, restauração, Urochloa.

Recebido para publicação em 12.11.2015 e aprovado em 19.4.2016.

2 Universidade Federal do Mato Grosso do Sul, Campo Grande-MS, Brasil; ${ }^{3}$ Universidade Anhanguera-UNIDERP, Campo GrandeMS, Brasil, <silviarahe@gmail.com>; ${ }^{4}$ Universidade Federal do Mato Grosso do Sul, Chapadão do Sul-MS; ${ }^{5}$ Embrapa Gado de Corte, Campo Grande-MS, Brasil. 


\section{INTRODUCTION}

Tropical ecosystems have been intensely altered in recent decades being, in many cases, converted into pastures (Cheung et al., 2010). Many of these areas, however, has been abandoned due to a decrease in productivity by soil exhaustion or changes in local economy (Ortega-Pieck et al., 2011). After extended periods of intense cultivation or abandonment, desirable target species are often no longer present in the seed bank and natural recolonization tends to be slow or unfeasible (Wagner et al., 2011). Therefore, active reintroduction is usually required. Several studies have shown the effectiveness of direct sowing of tree species in restoration projects, as a technique of lower cost and easier operation than seedling planting (Pereira et al., 2013a). However, there are still few examples of forests implantation by direct sowing in Latin America, being necessary studies that assess the effectiveness of this technique in pasture areas (Pereira et al., 2013b) and the factors which may negatively influence their use.

Competition with grasses may prevent seedlings survival and growth of tree species in pastures areas, as reported by Griscom et al. (2009), García-Orth and Martínez-Ramos (2011) and Pereira et al. (2013a). However, these studies do not determine for certain, if these results would be only due to exploration competition, or additionally, a consequence of interference competition. The interference competition, or allelopathy, occurs through production and release on the environment of substances from plants secondary metabolism (allelochemicals), which are toxic to other species.

This substances synthesis may interfere at some stage of another plant life cycle, since its germination (Silva et al., 2014). Some allelochemicals enhance oxidative enzyme activity, and as a final consequence, a change in membranes permeability and lignin biosynthesis, contributing to decrease of root elongation. Oxygen production is stimulated by allelochemicals by different mechanisms. Among them is blocking the transport chain of electrons, where electrons are free and easily react with $\mathrm{O}_{2}$ forming superoxide. The sorgoleone, a substance present in sorghum
(Sorghum bicolor) is able to inhibit photosynthesis by blocking the transport chain photosystem electron II to photosystem I (Gniazdowska and Bogatek, 2005), and increase production of oxygen reactive that works on species operating in the oxidative stress of the cell membranes. Another known mechanism in oxygen reactive species formation is the activity of allelochemicals on the NADPH oxidase, an enzyme that transfers electrons from NADPH and donates to an acceptor $\left(\mathrm{O}_{2}\right)$ to produce superoxide (Foreman et al., 2003).Thus, inhibition of the establishment of tree species in pasture areas could be attributed, at least in part, to allelopathy, and this interaction may represent an important limitation to establishment by altering both the patterns of germination and growth of these species.

African grasses of the Urochloa genus (known as Brachiaria grasses) are widely distributed in Latin America, introduced in the region for forage use. Only in Brazil, 95 million hectares are planted with Urochloa species, being 60 million of $U$. brizantha, 25 million of $U$. decumbens and 10 million of $U$. humidicola. and others (Laura et al., 2013). However, in many cases these species have become invasive to natural ecosystems in the region (Matos and Pivello, 2009). The genus characteristics, as sexual and vegetative reproduction, rapid reproductive cycle, high photosynthetic and nutrient use efficiency and high growth rates (Oliveira et al., 2006; Pires et al., 2012) make it highly competitive with native species. Furthermore, recent studies have demonstrated the allelopathic activity of the genus in different plant species (Barbosa et al., 2008; Contreiras-Rodrigues et al., 2012; Kato-Noguchi et al., 2014; Graat et al., 2015). Thus, studies that evaluate the influence of Urochloa genus on the establishment of tree species are important to provide information that supports the re-introduction of these in abandoned pastures. More specifically, in direct sowing projects, it would be important to evaluate the allelopathic potential of grass species on seed germination and seedling performance of tree species.

Guazuma ulmifolia, is a tree species with wide distribution throughout tropical America, 
found in areas of Cerrado, Atlantic Forest, Amazon Rainforest, Caatinga and Pantanal biomes. It is a pioneer species, with rapid growth, great adaptation to fire, low nutritional requirement, inhabiting both dry and moist sites and providing fruit for wildlife food (Carvalho, 2007). For all these features, it is a species widely used in restoration projects. However, there are no records in the literature addressing the influence of grasses of Urochloa genus on its germination and seedling development.

The aim of this study was to evaluate the allelopathic potential of $U$. brizantha and $U$. decumbens on seed germination, growth and metabolism of Guazuma ulmifolia seedlings.

\section{MATERIAL AND METHODS}

\section{Botanical material and ethanolic extract and semipurified fractions preparation}

To evaluate the allelopathic potential of $U$. brizantha and $U$. decumbens, adults from two species were collected (about three kilograms of fresh weight from each species) in December 2012, at Embrapa Beef Cattle fields, in Campo Grande, Mato Grosso do Sul State, Brazil (20²5'27"S, 5441'16' 'W). The collected material (above and below ground portions) was submitted to maceration with ethanol ( $1: 2 \mathrm{w} / \mathrm{v}$ ratio), at room temperature. After seven days, the solution was filtered and the solvent was evaporated in rotary evaporator under vacuum $\left( \pm 40{ }^{\circ} \mathrm{C}\right)$, in order to obtain the crude ethanolic extract (CEE). The CEE was fractioned by liquid-liquid partition with solvents of increasing polarity, hexane and ethyl acetate, resulting in the following semipurified fractions (SFs): the hexane fraction $(\mathrm{HF})$; the ethyl acetate fraction (EAF) and the etanol-water fraction (EWF). For the bioassays, a stock solution was prepared at a concentration of $1,000 \mathrm{mg} \mathrm{L}^{-1}$ based on the mass calculated for each CEE and SFs, taking the relative humidity into account, and the fractions were prepared for dilution by dissolution in $0.1 \%$ dimethyl sulfoxide (DMSO) (Dayan et al., 2000) at concentrations of $500 \mathrm{mg} \mathrm{L}^{-1}$ and $250 \mathrm{mg} \mathrm{L}^{-1}$. The solutions were buffered with $10 \mathrm{mM}$ MES (2-morpholinoethane sulfonic acid) solution and adjusted to $\mathrm{pH} 6.0$ with $0.1 \mathrm{~N} \mathrm{KOH}$ (potassium hydroxide) solution (Macias et al., 2000). As a control, a similar procedure was carried out without the CEEs or SFs. Thus, for each solution, different concentrations were used, as it follows: $1,000 \mathrm{mg} \mathrm{L}^{-1}, 500 \mathrm{mg} \mathrm{L}^{-1}, 250 \mathrm{mg} \mathrm{L}^{-1}$ and $0 \mathrm{mg} \mathrm{L}^{-1}$ (control).

\section{Germination bioassays}

Test solutions were assayed with G. ulmifolia seeds obtained from the Brazilian Institute of Forests (IBF). As this species has primary dormancy (Araújo-Neto and Aguiar, 2000; Paiva Sobrinho et al., 2012), the seeds were scarified with hot water at $100{ }^{\circ} \mathrm{C}$ for $5 \mathrm{~min}$ in order to overcome seeds dormancy (Carvalho, 2007). For the germination bioassays, $5.0 \mathrm{~mL}$ of each solution, at concentrations of $0,250,500$ and $1,000 \mathrm{mg} \mathrm{L}^{-1}$, were poured onto autoclaved Whatman no. 1 filter paper on Petri dishes $19.0 \mathrm{~cm}$ in diameter). Onto each filter paper, 50 seeds of G. ulmifolia were randomly distributed. This procedure was performed four times for each solution (Brasil, 2009). The Petri dishes were placed into a biological oxygen demand incubator (growth chamber), under a $160 \mathrm{~W}$ light, at a constant relative humidity $( \pm 80 \%)$ and constant temperature $\left(25^{\circ} \mathrm{C}\right.$ with a $12 \mathrm{~h}$ photoperiod). The variables evaluated were germination percentage and average germination time (AGT) according to Edmond and Drapala (1958). For this, daily counts were performed, using the physiological criterion of germination, being considered germinated seeds showing at least $2 \mathrm{~mm}$ length root protrusion (Juntila, 1976). The experiment was considered concluded when there was no new germination for three consecutive days (Ferreira and Aquila, 2000).

\section{Growth bioassays}

For growth bioassay was used the method described by Macias et al. (2000). First the seeds were germinated in Petri dishes containing distilled water, as described above. After germination (considered germinated seeds showing at least $2 \mathrm{~mm}$ length root protrusion), we selected 80 seedlings (four repetitions of 20) per treatment that were transferred to Petri dishes containing test 
solutions, using a similar procedure to that was described in germination bioassays (Macias et al., 2000). Five days after radicle protrusion, the length of the root and of the hypocotyl (ten seedlings per Petri dish) was measured by using millimeter paper.

\section{Effect on oxidative stress}

For the evaluation of oxidative stress, $1.0 \mathrm{~g}$ of fresh seedlings (taken from the growth bioassay) was crushed in a mortar with liquid nitrogen $(6.0 \mathrm{~mL} ; 0.2 \mathrm{M} ; \mathrm{pH} 7.0)$. The resultant mass was homogenized with $50 \mathrm{nM}$ S-phosphate buffer ( $\mathrm{pH} 7.0$ ) containing $2.0 \mathrm{mM}$ EDTA (ethylenediamine tetraacetic acid) and PVP (Polivinilpirrolidona) 1.0\%. The supernatant was collected and used as crude extract for dosages of peroxidase e catalase enzymes activities (Zeng et al., 2001). For peroxidase activity (POD), a $10 \mu \mathrm{L}$ extract aliquot was added to test tubes containing $1.0 \mathrm{~mL}$ of $\mathrm{K}$-phosphate $(\mathrm{pH} 7.0)$; then the tubes were brought into bain-marie until the stabilization of temperature at $25{ }^{\circ} \mathrm{C}$. Subsequently, there was added $100 \mu \mathrm{L}$ of guaiacol $(0.5 \%), 100 \mu \mathrm{L}$ of $\mathrm{H}_{2} \mathrm{O}_{2}(0.08 \%)$, and immediately absorbance readings were made with a spectrophotometer absorbance at $\mathrm{nm}$ with three replications for each treatment. The activity of POD was calculated by using the extinction coefficient of $25.5 \mathrm{mM}^{-1} \mathrm{~cm}^{-1}$ and the result was expressed in tetraguaiacol produced $\left(\mathrm{mg}\right.$ protein $\left.{ }^{-1}\right)$. For catalase activity (CAT) evaluation, $100 \mu \mathrm{L}$ of enzyme extract was added to $3.0 \mathrm{~mL}$ of hydrogen peroxide $\left(\mathrm{H}_{2} \mathrm{O}_{2}\right)$ $(12.5 \mathrm{mM})$ in potassium phosphate buffer (50 mM; pH 7.0) at $30^{\circ} \mathrm{C}$. Then the readings of absorbance were carried out at $240 \mathrm{~nm}$, with three replications for each treatment (Cakmak and Marschner, 1992).

\section{Total chlorophyll determination and formazan production}

To determine the chlorophyll content, $20 \mathrm{mg}$ of the aerial portions of G. ulmifolia seedlings, from the growth bioassay, were crushed in a mortar and the chlorophyll was extracted with DMSO $0,1 \%$. After this the mash was allowed to stand in the dark for 24 hours at room temperature (Cayon et al., 1990). After this period, the absorbance of the solutions containing chlorophyll measured by a spectrophotometer at wavelengths of 645 and $663 \mathrm{~nm}$, and from these data, we calculated the total chlorophyll content according to Arnon (1949), as follows: Chlorophyll total $=20.2$ $\mathrm{xABsA}+8.02 \times \mathrm{Abs} \mathrm{B}$, where $\mathrm{ABs} A=$ absorbance of chlorophyll a; $\mathrm{AbsB}=$ absorbance of chlorophyll b. The substance absorptions were measured by a spectrophotometer at wavelengths of 645 and $663 \mathrm{~nm}$, and total chlorophyll content was calculated.

The potential respiration of root cells was estimated by Formazan production in radicle cells, estimated through the reduction of triphenyl tetrazolium chloride (TTC). For this evaluation, the roots were clipped at $1.0 \mathrm{~cm}$ from the hood and their masses were recorded (20 mg). They were then transferred to testtubes, where 0.6 TTC $(\mathrm{w} / \mathrm{v})$ was added $(3.0 \mathrm{~mL})$, along with $0.05 \mathrm{M}$ phosphate buffer ( $\mathrm{pH}$ 7.0). The test-tubes containing the roots were kept under vacuum in a desiccator for two hours and then transferred to bain-marie at $30^{\circ} \mathrm{C}$ for 15 hours. After this period, TTC solutions were drained and roots were washed. The test tubes containing the roots were transferred again to bain-marie in boiling water $\left( \pm 100{ }^{\circ} \mathrm{C}\right)$, then $7.0 \mathrm{~mL}$ of ethanol $95 \%(\mathrm{v} / \mathrm{v})$ was added. After cooling at room temperature, the roots were removed and ethanol 95\% (v/v) was added to each solution. Absorbances of ethanolic solutions were measured in a spectrophotometer at $530 \mathrm{~nm}$ of wavelength. The results are expressed in absorbance values (Steponkus and Lanphear, 1967).

\section{Statistical analysis}

For each test, CEE and SFs were evaluated, using a experimental design was completely randomized, with four treatments $(0,250,500$ and $1,000 \mathrm{mg} \mathrm{L}^{-1}$ ) performed four times. The collected data (germination, germination speed index, shoot and root growth, peroxidase and catalase activities, total chlorophyll content and absorbance) were evaluated with analysis of variance (ANOVA). When the F-test indicated a difference, the means were compared with Tukey's tests, at a 5\% level of statistic significance. The germination data (\%) were transformed into arcsine square root for statistical analysis as recommended by Santana and Ranal (2004). 


\section{RESULTS AND DISCUSSION}

Test solutions of $U$. brizantha and $U$. decumbens have inhibited germination of G. ulmifolia in a dosage-dependent manner. In general, the increase in the concentration of the tested solutions resulted in a greater reduction in germination percentage (Table 1). Except for the EWF, the average germination time was also influenced by the use of test solutions (Table 1). For CEE, HF and $\mathrm{EAF}$, regardless of the concentration used, the exposure of seeds to extract and fractions resulted in slower germination compared to the control.

The two grass species evaluated reduced the growth of both shoot and root portions of G. ulmifolia seedlings (Figure 1). For $U$. brizantha it was noted that in the presence of any test solution, regardless of the concentration, there was inhibition of shoot growth of G. ulmifolia seedlings. For $U$. decumbens, an inversely proportional relation was found being that an increase in the concentration of the solutions used resulted in a greater reduction in hypocotyl length of G. ulmifolia seedlings. This second pattern is similar to that found for the seedlings root growth of G. ulmifolia, submitted to both $U$. brizantha and $U$. decumbens.

The catalase activity was positively related to the increase in concentration of the test solutions evaluated, except in the EWF solution of $U$. brizantha, where increased concentration of the solution resulted in reduction of enzyme production compared to the control (Figure 2). The enzymatic activity of peroxidase (POD) in G. ulmifolia seedlings varied depending on the specie of Urochloa evaluated. For U. brizantha, production of POD increased significantly at different concentrations of CEE, EAF and EWF solutions compared to control. For HF solution, no differences were found for POD activity. G. ulmifolia seedlings subjected to solutions of $U$. decumbens showed increased POD activity only at highest concentrations of test solutions (Figure 2).

The chlorophyll production in G. ulmifolia seedlings showed distinct patterns of response according to the Urochloa species. (Figure 3). To $U$. brizantha it was observed an increased production of chlorophyll in the CEE, EAF and EWF solutions, while HF solution did not influence this variable. To $U$. decumbens, the same pattern of increase of chlorophyll production by G. ulmifolia seedlings was

Table 1 - Effect of different concentrations of crude etanol extract (CEE), hexane fraction (HF), ethyl acetate fraction (EAF) and ethanol-water fraction (EWF) of Urochloa brizantha and U. decumbens on the germination (\%) average germination time (AGT) of Guazuma ulmifolia

\begin{tabular}{|c|c|c|c|c|c|c|c|}
\hline \multicolumn{4}{|c|}{ Urochloa brizantha extracts } & \multicolumn{4}{|c|}{ Urochloa decumbens extracts } \\
\hline \multicolumn{4}{|c|}{ Germination $(\%)$} & \multicolumn{4}{|c|}{ Germination (\%) } \\
\hline Treatment & $250 \mathrm{mg} \mathrm{L}^{-1}$ & $500 \mathrm{~m} \mathrm{~L}^{-1}$ & $1000 \mathrm{mg} \mathrm{L}^{-1}$ & Treatment & $250 \mathrm{mg} \mathrm{L}^{-1}$ & $500 \mathrm{mg} \mathrm{L}^{-1}$ & $1000 \mathrm{mg} \mathrm{L}^{-1}$ \\
\hline \multicolumn{4}{|c|}{ Control: 60.0} & \multicolumn{4}{|c|}{ Control: 60.0} \\
\hline CEE & $56 \mathrm{a}$ & $40 \mathrm{~b}$ & $26 \mathrm{c}$ & $\mathrm{CEE}$ & $47 \mathrm{~b}$ & $43 \mathrm{~b}$ & $14 \mathrm{c}$ \\
\hline $\mathrm{HF}$ & $20 \mathrm{~b}$ & $17 \mathrm{bc}$ & $10 \mathrm{c}$ & $\mathrm{HF}$ & $55 \mathrm{a}$ & $45 \mathrm{~b}$ & $23 \mathrm{c}$ \\
\hline EAF & $28 \mathrm{~b}$ & $18 \mathrm{c}$ & $6 \mathrm{~d}$ & EAF & $54 \mathrm{a}$ & $52 \mathrm{a}$ & $28 \mathrm{~b}$ \\
\hline EWF & $34 \mathrm{~b}$ & $27 \mathrm{~b}$ & $18 \mathrm{c}$ & EWF & $53 \mathrm{ab}$ & $44 \mathrm{bc}$ & $32 \mathrm{c}$ \\
\hline \multicolumn{4}{|c|}{$\begin{array}{c}\text { Urochloa brizantha extracts } \\
\text { Average Germination time (AGT) }\end{array}$} & \multicolumn{4}{|c|}{$\begin{array}{c}\text { Urochloa decumbens extracts } \\
\text { Average Germination time (AGT) }\end{array}$} \\
\hline Treatment & $250 \mathrm{mg} \mathrm{L}^{-1}$ & $500 \mathrm{~m} \mathrm{~L}^{-1}$ & $1000 \mathrm{mg} \mathrm{L}^{-1}$ & Treatment & $250 \mathrm{mg} \mathrm{L}^{-1}$ & $500 \mathrm{mg} \mathrm{L}^{-1}$ & $1000 \mathrm{mg} \mathrm{L}^{-1}$ \\
\hline \multicolumn{4}{|c|}{ Control: $5.9 \mathrm{a}$} & \multicolumn{4}{|c|}{ Control: $5.9 \mathrm{a}$} \\
\hline CEE & $7.1 \mathrm{~b}$ & $7.0 \mathrm{~b}$ & $7.5 \mathrm{~b}$ & CEE & $8.1 \mathrm{~b}$ & $8.1 \mathrm{~b}$ & $9.2 \mathrm{~b}$ \\
\hline $\mathrm{HF}$ & $10.8 \mathrm{~b}$ & $10.9 \mathrm{~b}$ & $11.9 \mathrm{~b}$ & $\mathrm{HF}$ & $6.8 \mathrm{~b}$ & $7.4 \mathrm{~b}$ & $7.1 \mathrm{~b}$ \\
\hline EAF & $10.4 \mathrm{~b}$ & $10.7 \mathrm{~b}$ & $10.2 \mathrm{~b}$ & EAF & $8.9 \mathrm{~b}$ & $9.3 \mathrm{~b}$ & $9.5 \mathrm{~b}$ \\
\hline EWF & $10.8 \mathrm{a}$ & $9.6 \mathrm{a}$ & $7.9 \mathrm{a}$ & EWF & $7.7 \mathrm{a}$ & $8.4 \mathrm{a}$ & $8.7 \mathrm{a}$ \\
\hline
\end{tabular}

Means followed by the same letter in each line do not differ significantly $(\mathrm{p}<0.05)$ as compared to control (Tukey test). 

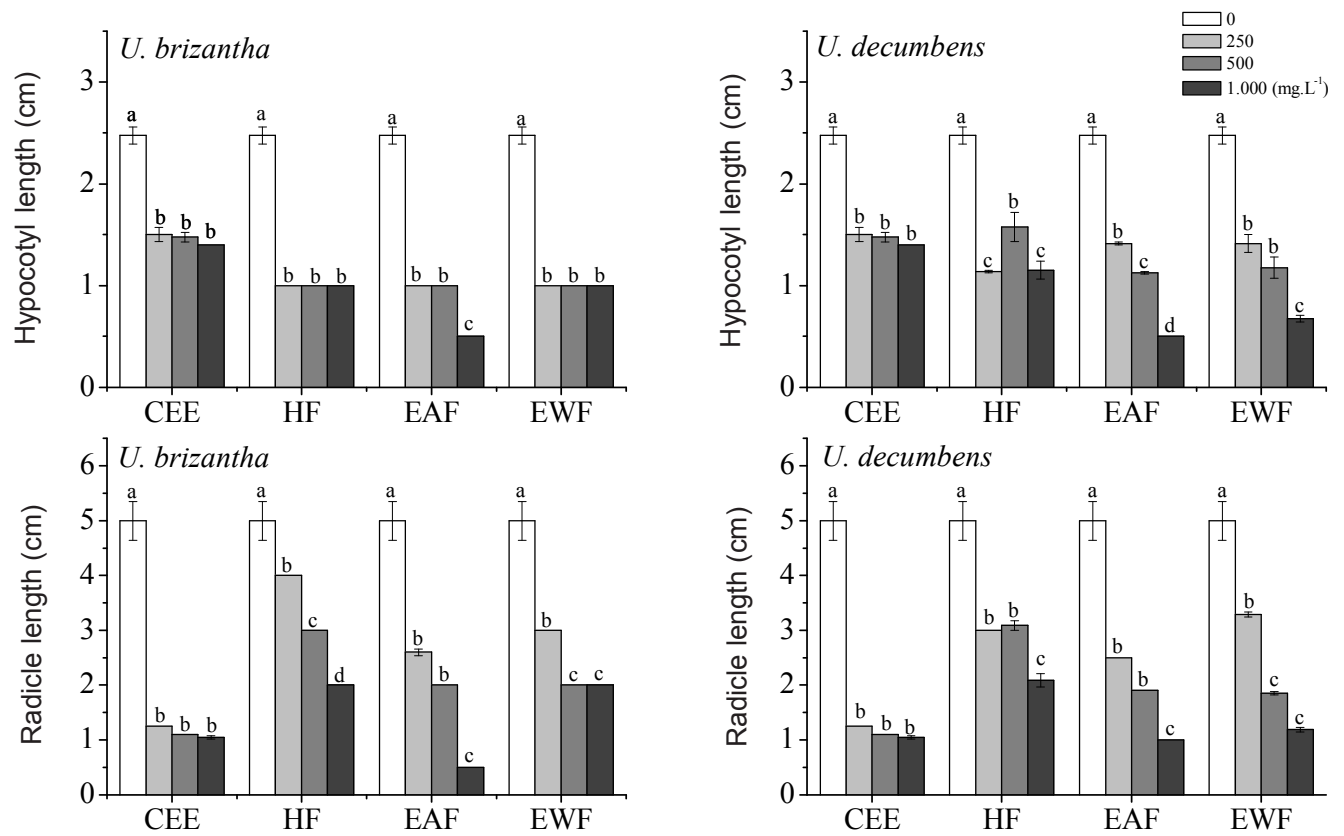

$\mathrm{CEE}=$ crude etanol extract; $\mathrm{HF}=$ hexane fraction; $\mathrm{EAF}=$ ethyl acetate fraction; $\mathrm{EWF}=$ ethanol-water fraction. Different letters differ significantly $(\mathrm{p}<0.05)$ as compared to control (Tukey test).

Figure 1 - Effect of different concentrations of Urochloa brizantha and $U$. decumbens extracts on hipocotyl and radicle size of Guazuma ulmifolia seedlings.
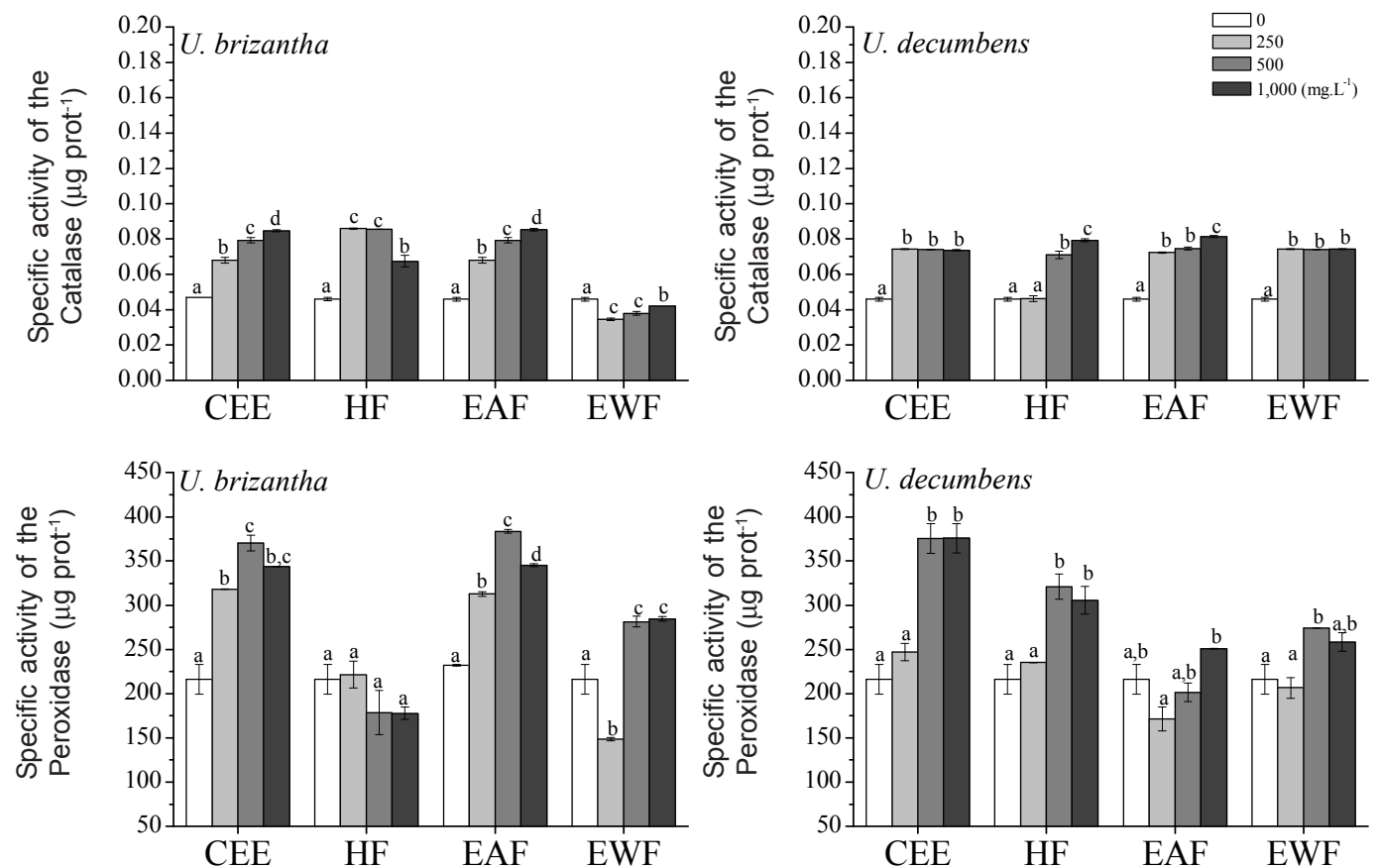

$\mathrm{CEE}=$ crude etanol extract $\mathrm{HF}=$ hexane fraction; $\mathrm{EAF}=$ ethyl acetate fraction; EWF $=$ ethanol-water fraction. Different letters differ significantly $(\mathrm{p}<0.05)$ as compared to control (Tukey test).

Figure 2 - Effect of different concentrations of Urochloa brizantha and U. decumbens extracts on peroxidase and catalase activity of Guazuma ulmifolia seedlings. 
observed in the CEE and EWF solutions. HF solution did not influence chlorophyll production and high concentrations of EAF solution reduced its production. The respiratory activity of the root cells of the G. ulmifolia seedlings was reduced in all tested $U$. brizantha solutions. Yet, in the presence of $U$. decumbens, except for $\mathrm{HF}$ fraction, an increase in the concentration of test solutions resulted in increased respiratory activity of roots of G. ulmifolia seedlings.

Seed germination bioassays in the presence of plant extracts are starting points for investigation of intra and interspecific allelopathy effects. Both Urochloa species inhibited G. ulmifolia germination (Table 1). In the field, seed germination prevention due to toxic chemical substances may result in decrease of individuals density which, in medium and long term, can lead to local extinction of this species, with implications for local biodiversity (Callaway et al., 2005; Rech et al., 2015). Thus, the reintroduction of G. ulmifolia using direct seeding in pasture areas, besides considering the amount of seed to be used according to their germination potential (the seeds used in this study were $60 \%)$, must additionally predict additional reduction in germination due to the allelopathic effect offered by grasses.

Some studies show that, in addition to germination percentage, the germination pattern (speed and synchrony) can also be modified by the action of allelochemicals (Santana et al., 2006). We found this effect in the present study, by the G. umlifolia AGT modification under the influence of the two grasses (Table 1). The germination delay, due to the allelopathic effect found, can result in reducing the likelihood of species establishment under field conditions. Seeds that are slow to germinate are subjected to prolonged exposure to natural enemies, such as soil fungi and vertebrates and invertebrates predators, increasing the chances of mortality of individuals still in the seed stage (Pereira et al., 2013b). Furthermore, restoration projects tend to be implemented in the season with greater water availability, particularly in regions with water deficit for prolonged periods.
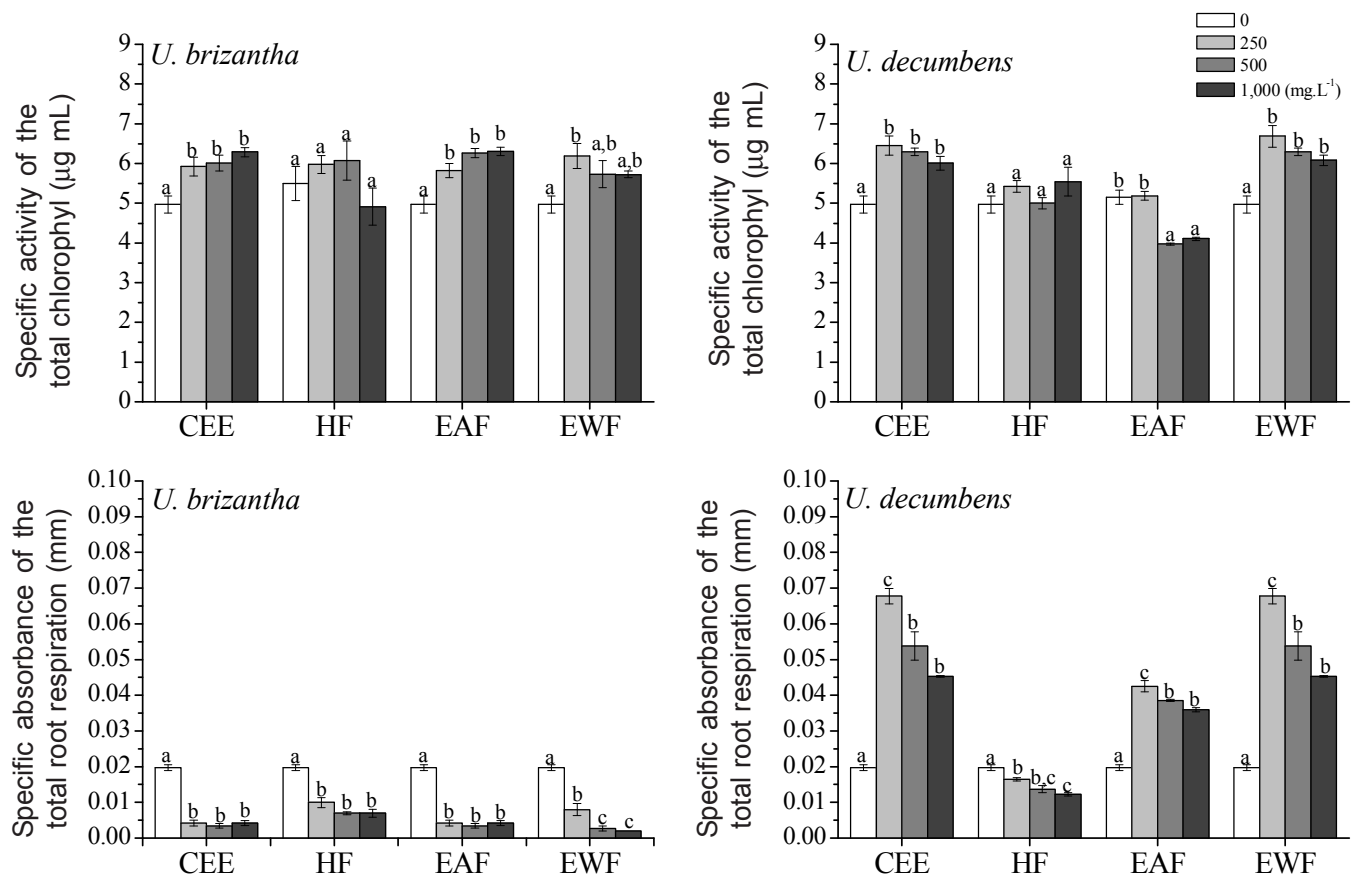

$\mathrm{CEE}=$ crude etanol extract; $\mathrm{HF}=$ hexane fraction; $\mathrm{EAF}=$ ethyl acetate fraction; EWF $=$ ethanol-water fraction. Different letters differ significantly $(\mathrm{p}<0.05)$ as compared to control (Tukey test).

Figure 3 - Effect of different concentrations of Urochloa brizantha and U. decumbens extracts on chlorophyll content and root respiration of Guazuma ulmifolia seedlings. 
Thus, seed germination delay could still result in the failure of seedling establishment, if the water availability has already become very small (Pereira et al., 2013b).

Besides the changes in seed germination changes in the seedlings size were also detected due to the presence of test solutions of both grasses evaluated. The results showed that test solutions inhibit both shoot and root growth of G. ulmifolia (Figures 1 and 2), with inhibition values exceeding $60 \%$. According to Alves and Santos (2002), the change in the seedling organs length is related to changes in the plant hormonal balance. Reducing the seedlings size may represent a second obstacle to the establishment of tree species in pastures, since larger plants tend to have advantages through early access to water in deeper soil layers and be potentially better competitors (Schmidt, 2008; Larson et al., 2011; Pereira et al., 2013a). Thus, the initial seedling size of tree species, resulting from allelopathic interference, may influence the competitive ability of seedlings for soil resources, altering the patterns of species establishment.

Plants are the most abundant source for the oxidoreductase enzyme class. The peroxidase and catalase are part of this group, working in the antioxidative protection and also catalyzing a variety of reactions involving electrons transfer (Chance and Maehly, 1955). According to Sinsabaugh (2010), the expression of these enzymes appears to be a response to oxidative stress and the presence of phenolic compounds, indicating that their are related to plant defense mechanisms under stress. In the present study, we detected an increase in the peroxidase (POD) and catalase (CAT) activity in G. ulmifolia seedlings subjected to grass test solutions (Figure 3), suggesting that they could have a negative effect on the tree species studied. The enhanced activity of oxidative enzymes induced by the allelochemicals action, can modify the permeability of cell membranes and the formation and deposition of lignin, contributing to the reduction of root elongation (Ferrarese et al., 2000). Thus, the oxidative stress, resulting from high concentrations of the test solutions could be one of the factors contributing to the reduction in seedlings size observed in this study (Figure 2).

The chlorophyll production in G. ulmifolia was stimulated by the two grasses tested. With an attempt of species acclimation, the increase of chlorophyll can be related with its photoprotective function and energy capture for photosynthesis (Marenco and Lopes, 2005). Besides the photosynthetic respect, the presence of allelochemicals can also alter cellular respiration interfering with various stages of this process (Chon et al., 2000). The cell respiration response observed in the present study was species-dependent, being that $U$. brizantha reduced G. ulmifolia root respiration rates and $U$. decumbens, in a general way, caused an increase in the root cellular respiration rate. Burgos et al. (2004) have shown that allelochemicals produced by Secale cereale reduced root growth of Cucumis sativus, because they changed root cellular structure. According to Song et al. (1996) disturbances in cell membranes result in changes in membrane permeability, destruction of chloroplasts, mitochondria, nucleus and endoplasmic reticulum, finally resulting in reduced photosynthesis and plant growth.

The results obtained show that extracts of $U$. brizantha and $U$. decumbens have an inhibitory effect on the G. ulmifolia metabolism, affecting both germination and seedlings growth. We also found an increase of antioxidant enzymes activity, which indicates an induction of metabolic defense in response to the extracts. All these metabolic processes are important for the establishment of plant species and the data obtained show that the grass species evaluated have the potential to restrict the re-introduction of G. ulmifolia in pasture areas, via direct sowing, due to interference competition.

The results obtained show that extracts of $U$. brizantha and $U$. decumbens affects G. ulmifolia metabolism, reducing both germination and seedlings growth and increasing of antioxidant enzymes activity, which may indicate an induction of metabolic defense in response to the extracts. It is also can be inferred that the grass species evaluated have the potential to restrict the 
re-introduction of G. ulmifolia in pasture areas, via direct sowing, due to interference competition.

\section{ACKNOWLEDGEMENTS}

We would like to thank the Coordination for the Improvement of Higher Level -or Education-Personnel (CAPES) by funding this study by maintaining scholarships for the first author and Fundação Manoel de Barros for the financial support to perform this research.

\section{REFERENCES}

Alves S.M., Santos L.S. Natureza química dos agentes alelopáticos, In: Souza Filho, A.P.S., Alves, S.M., editores. Alelopatia: princípios básicos e aspectos gerais. Belém: Embrapa Amazônia Oriental, 2001. p.25-47.

Araújo-Neto J.C., Aguiar I.B. Tratamentos pré-germinativos para superar a dormência de sementes de Guazuma ulmifolia Lam. Sci For. 2000;58:15-24.

Arnon D.I. Copper enzymes in isolated chloroplasts. Polyphenoloxidase in Beta vulgaris. Plant Physiol. 1949;24:1-15.

Barbosa E.G., Pivello V.R., Meirelles S.T. Allelopathic evidence in Brachiaria decumbens and its potential to invade the Brazilian Cerrados. Braz Arch Biol Technol. 2008;51:825-31.

Brasil. Regras para análise de sementes. Brasília: SNDA/ DNDV/CLAV, 2009. 395p.

Burgos N.R. et al. Growth inhibition and root ultrastructure of cucumber seedlings exposed to allelochemicals from rye (Secale cereale). J Chem Ecol. 2004;30:671-89.

Cakmak I., Marschner H. Magnesium deficiency and high light intensity enhance activities of superoxide dismutase, ascorbate peroxidase and glutathione reductase in bean leaves. Plant Physiol. 1992;98:1222-7.

Callaway R.M. et al. Natural selection for resistance to the allelopathic effects of invasive plants. J Ecol. 2005;93:57683.

Carvalho P.E.R. Mutamba: Guazuma ulmifolia. Colombo: Embrapa Florestas, 2007. 13p.

Cayon D.G. et al. Teores de clorofilas e de proteína bruta em soja (Glycine max (L.) Merril) tratada com imazaquin. Rev Bras Fisiol Veg. 1990;2:33-40.
Chance B., Maehly A.C. Assay of catalase and peroxidase Meth Enzymol. 1955;2:764-75.

Cheung K.C., Liebsch D., Marques M.C.M. Forest recovery in newly abandoned pastures in Southern Brazil: implications for the Atlantic Rain Forest resilience. Nat Conserv. 2010;8:66-70.

Chon S.U. et al. Effects of light, growth media and seedling orientation on bioassays of alfafa autotoxicity. Agron J. 2000;92:715-20.

Contreiras-Rodrigues A.P.D. et al. Alelopatia de duas espécies de braquiária em sementes de três espécies de estilosantes. Ci Rural. 2012;42:1758-63.

Dayan F.E. et al. Investigating the mode of action of natural phytotoxins. J Chem Ecol. 2000;26:2079-93.

Edmond J.B., Drapala W.J. The effects of temperature, sand and soil, and acetone on germination of okra seed. Proc Am Soc Hortic Sci. 1958;71:428-34.

Ferrarese M.L.L. et al. Ferulic acid uptake by soybean root in nutrient culture. Acta Physiol Plant. 2000;22:121-4.

Ferreira A.G., Aqüila M.E.A. Alellopathy: an emerging topic in ecophysiology. Rev Brasil Fisiol Veg. 2000;12:175-204.

Foreman J.V. et al. Reactive oxygen species produced by NADPH oxidase regulate plant cell growth. Nature. 2003;422:442-5.

García-Orth X., Martínez-Ramos M. Isolated trees and grass removal improve performance of transplanted Trema micrantha (L.) blume (Ulmaceae) saplings in tropical pastures. Rest Ecol. 2011;19:24-34.

Gniazdowska A., Bogatek R. Allelopathic interactions between plants. Multisite action of allelochemicals. Acta Physiol Plant. 2005;27:395-407.

Graat Y. et al. Grass weeds interfering with eucalypt: effects of the distance of coexistence on the initial plant growth. Planta Daninha. 2015;33:203-11.

Griscom H.P. et al. Forest regeneration from pasture in the dry tropics of panama: effects of cattle, exotic grass, and forested riparia. Rest Ecol. 2009; 17:17-126.

Juntila O. Seed and embryo germination in S. vulgaris and $S$ reflexa as affected by temperature during seed development. Physiol Plant. 1976;29:264-8.

Kato-Noguchia H. et al. Phytotoxic substances with allelopathic activity may be central to the strong invasive potential of Brachiaria brizantha. J Plant Physiol. 2014;171:525-30. 
Larson D.L. et al. Effects of planting method and seed mix richness on the early stages of tall grass prairie restoration. Biol Conserv. 2011;144:3127-39.

Laura, V.A. et al. Qualidade de sementes nuas e recobertas de braquiárias. Campo Grande: Embrapa Gado de Corte, 2013. 18p.

Macias F.A. et al. Sesquiterpene lactones with potencial use as natural herbicides models. 2. guaianolides. J Agric Food Chem. 2000;48:5288-96.

Marenco R.A., Lopes N.F. Fisiologia vegetal: fotossíntese, respiração, relações hídricas e nutrição mineral. Viçosa, MG: Universidade Federal de Viçosa, 2005. 486p.

Matos D.M.S., Pivello V.R. O impacto das plantas invasoras nos recursos naturais de ambientes terrestres - alguns casos brasileiros. Ci Cult. 2009;61:27-30.

Oliveira Y. et al. Botanical and agronomic characteristics of important forage species of the Brachiaria genus. Pastos For. 2006;29:14-23.

Ortega-Piecka A. et al. Early seedling establishment of two tropical montane cloud forest tree species: the role of native and exotic grasses. For Ecol Manage. 2011;261:1336-43.

Paiva Sobrinho S. Superação da dormência em sementes de mutamba (Guazuma ulmifolia Lam. - Sterculiaceae). Rev Árvore. 2012;36:797-802.

Pereira S.R. et al. Establishment of Fabaceae tree species in a tropical pasture: influence of seed size and weeding methods. Rest Ecol. 2013a;21:67 4.

Pereira S.R. et al. Seed dormancy overcoming as a strategy for forest restoration in tropical pasture. Pesq Agropec Bras. 2013b:48:148-56.
Pires A.C.V et al. Efeito de Brachiaria decumbensna herbivoria e no desenvolvimento de duas leguminosas nativas de Cerrado. Planta Daninha. 2012;30:737-46.

Rech K. et al. Croton argenteus preparation inhibits initial growth, mitochondrial respiration and increase the oxidative stress from Senna occidentalis seedlings. An Acad Bras Ci. 2015;87:753-63.

Santana D.G., Ranal M.A. Análise da germinação: um enfoque estatístico. Brasília: UnB, 2004. 248p.

Santana, D.G. et al.Germination measurements to evaluate allelopathic interactions. Allelop J. 2006;17:43-52.

Schmidt L. A review of direct sowing versus planting in tropical afforestation and land rehabilitation. Copenhagen: Forest \& Landscape Denmark, 2008.37p.

Silva C.B. et al. Sensitivity of Brachiaria decumbens and Ipomoea cordifolia to cyclic polysulfides from leaves of Microlobius foetidus. Allelop J. 2014;33:213-26.

Sinsabaugh R. Phenol oxidase, peroxidase and organic matter dynamics of soil. Soil Biol Biochem. 2010;42:391-404.

Song F.M. et al. Role of active oxygen and membrane lipid peroxidation in plant pathogen interactions. Plant Physiol Comm. 996;32:377-85.

Steponkus P.L., Lanphear F.O. Refinement of the triphenyl tetrazolium chloride method of determining cold injury. Plant Physiol. 1967;42:1423-6.

Wagner M. et al. The germination niches of grassland species targeted for restoration: effects of seed pre-treatments. Seed Sci Res. 2011;21:117-31.

Zeng R.S. et al. Physiological and biochemical mechanism of allelopathy of secalonic acid f on higher plants. Agron J. 2001;93:72-9. 